\title{
Effect of Laser on the Bone Defects Healing in Rats: An Experimental Study
}

\author{
Aleksa Marković, Radojica Dražić, Snježana Čolić \\ Clinic of Oral Surgery, School of Dentistry, University of Belgrade, Belgrade, Serbia
}

\begin{abstract}
SUMMARY
Introduction The stimulating effect of low-power laser on the process of wound healing is characterized by proliferation of fibroblasts, collagen production, and enhanced enzyme activity. The aim of this study was to evaluate the possible enhancing effect of low-power laser on the rate of the healing artificially created osseous defects in rats.

Material and methods Ten albino Wister rats were involved in this experimental study. Ro $2 \mathrm{~mm}$ deep) were made in each rat on both femurs. The right side was experimental whi' the left de was control. Osseous defects on the experimental side were daily treated with Galium, Aluminium, A enid (GaA As) low-power laser (Medicolaser 637, Technoline, Belgrade, Serbia), at the energy output of $4 \mathrm{~J} / \mathrm{cm}^{2}$ with co stant $r$ wer density of $50 \mathrm{~mW}$, and a wave length $637 \mathrm{~nm}$ (visible red light) per defect during seven day Jefect on t, ntrol side healed spontaneously. The effects of laser were evaluated two and three weeks postop

Results Histological analysis showed the powerful osteoblastic activity on bon efects the experimental side two weeks after surgery. On the control side, a new bone formation was aced at the phery of the bone defects but fibroblastic tissue with no signs of new bone was presented in the centra - eas. Three weeks after surgery, on the experimental side, bone defects were completely filled with spongi_lamellar ne while non-treated bone defects were characterized by mature lamellar bone at the peripheral ar as and immature bone at the central areas. Conclusion The results showed that the use of low-power las could hat a significant influence on the speed of curing bone defects in rats.
\end{abstract}

Keywords: low-power laser; GaAIAs laser; bone defect; On healing; usteoblastic activity; experimental study

\section{INTRODUCTION}

Bone healing includes the following st induc of acute inflammation, regeneration o paro hymal cils, migration and proliferation of $\mathrm{p}$ a Anchymal a d connective tissue cells, synthesis of rotein and extracellular matrix, remodelling of conn tive assue and parenchymal component and colla for $\mathrm{ng}[1]$ ooth extraction and removal of the ch onic priapic. sion can cause the defects in the jaw bo $\mathrm{He}$ the bone socket is similar with bone healing $\mathrm{h}$ eneral and includes the following stages [2]: formation a blood clot, organisation of the clot, making the epithelial cover of the surface of the wound, formation of the woven bone in the connective tissue filling, and replacement of the woven bone (which is characterized by lacunae not arranged in parallel rows) by the trabecular bone (the mature form of bone where collagen fibers in the bone matrix are organized into successive sheets or lamellae oriented in the same direction) and remodelling the socket [3].

Non-disturbed healing of bone defects and filling the wound with bone tissue is the main prerequisite for normal bone function. A period of approximately six months after creating a bone defect in humans (after tooth extraction or periapical surgery) is necessary for the formation of the lamellar bone and even more is needed following surgery for a defect to completely fill with mature bone tissue.

An ideal technique for wound healing stimulation, inducing more rapid bone regeneration, has not been resented yet. The regenerative procedure has not been accelerated even with new bone substitute materials [4]. Numerous data from literature shows the stimulating effect of soft (low-power) lasers on the process of wound healing $[5,6]$. This effect is characterized by proliferation of fibroblasts, faster collagen production and enhanced enzyme activity. However, there are no precise data concerning the influence of low-power lasers on the speed and degree of bone regeneration.

The aim of this study was to evaluate the possible enhancing effect of the GaAlAs low-power laser on the rate of the healing artificially created osseous defects in rats.

\section{MATERIAL AND METHODS}

The study was carried out on 10 albino Wister-rats, weighing $440 \pm 31$ g. Procedures were performed under intraperitoneal anaesthesia with Nembutal $(0.1 \mathrm{ml}$ per $100 \mathrm{~g}$ of body weight). The skin was shaved under the right (experimental side) and left (control side) femur region. The skin was cut and the femur was exposed by blunt preparation. The periosteum was cut, and round defects ( $3 \mathrm{~mm}$ wide $2 \mathrm{~mm}$ deep) were made in the bone at both sides using a round steal bur (Figure 1). Efforts were made not to open the bone marrow space. The periosteum, soft tissue and skin were sutured with catgut (4-0) thereafter.

Immediately after the operation, defects from the experimental (right) side were treated daily with 
Galium, Aluminium, Arsenid (GaAlAs) low-power laser (Medicolaser 637, Technoline, Belgrade, Serbia) at the energy output of $4 \mathrm{~J} / \mathrm{cm}^{2}$, with constant power density of $50 \mathrm{~mW}$, and a wave length $637 \mathrm{~nm}$ (visible red light) per defect during seven days. The treated area included

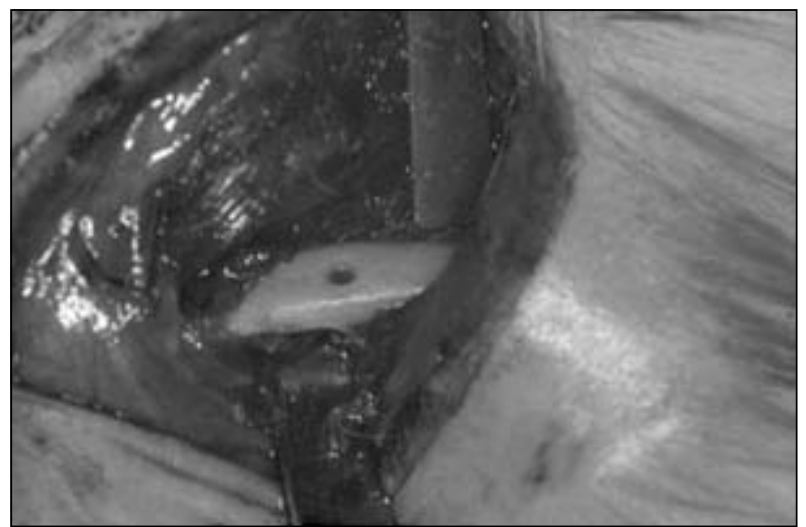

Figure 1. Bone defects of rat's femur $(2 \times 3 \mathrm{~mm})$

Slika 1. Oštećenje butne kosti pacova $(2 \times 3 \mathrm{~mm})$

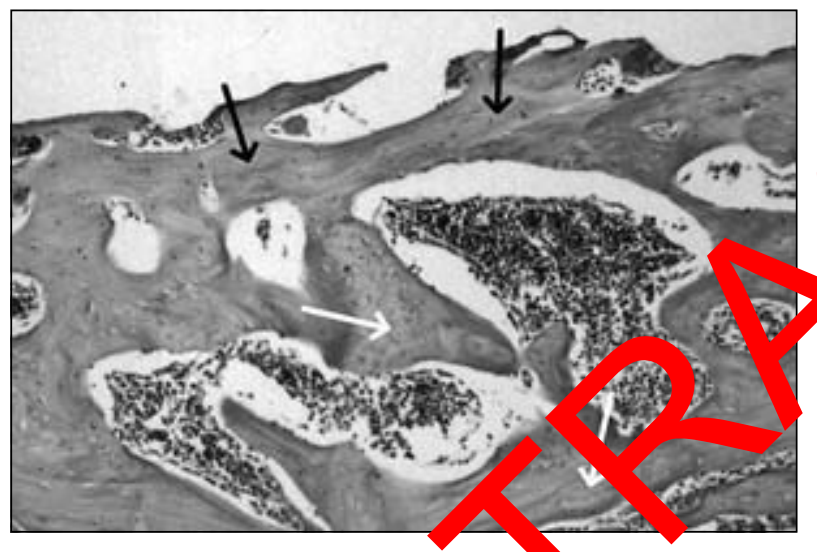

Figure 2. Defects of femur tre? with low- $\mathrm{d}$ wer laser showing powerful osteoblastic activity ith considerably nore mature bone (black arrow) than immatur white ow) after two weeks (H.E. 33x) Slika 2. Oštećenja butne kost na laser 1 male snage koji pokazuju snažnu osteobla nur ivnos zy no zrelijom kosti (crna strelica) nego nezrels (bela o elica) po dve nedelje (H.E. 33x)

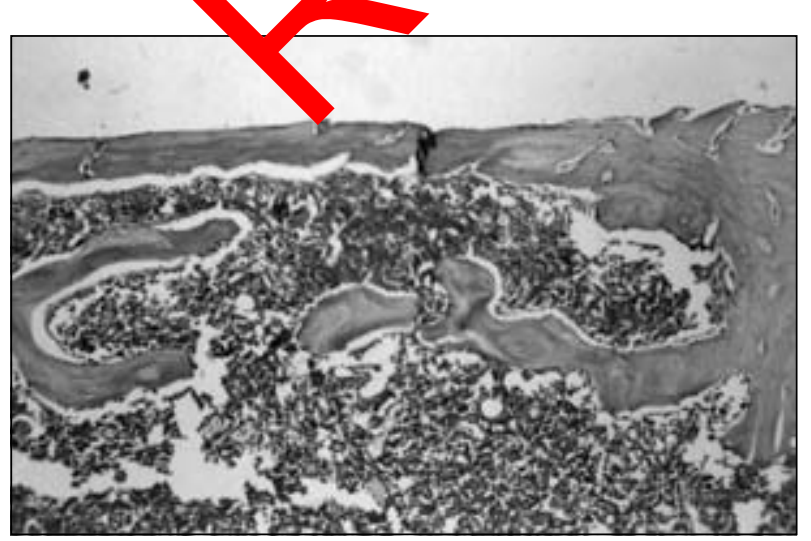

Figure 3. Defects of the control group, two weeks after surgery, osteoblastic activity is noticed. Newly formed bone sprouts are at the periphery of bone defects, and fibroblastic tissue with no signs of new bone formation in the central area of the bone defects (H.E. 33x).

Slika 3. Oštećenja kosti pacova kontrolne grupe dve nedelje nakon operacije sa osteoblastnom aktivnošću. Uočavaju se novoformirani koštani izdanci na periferiji, a u centralnom delu oštećenja je fibroblastno tkivo bez znakova stvaranja nove kosti (H.E. 33x). the defect and the skin around it. Bone defects from the control (left) side were allowed to heal spontaneously.

Half of the experimental animals (5 animals) were sacrificed 2 weeks after surgery and the rest of them ( 5 animals) after 3 weeks. The femurs were completely extracted and fixed in $10 \%$ formaldehyde; following by $20 \%$ ethylenediaminetetraacetat (EDTA) for a period of 2 weeks. Decalcified material was embedded in paraffin blocks. The samples were stained with haematoxylin-eosin and analysed under optical microscope. Five sections per each defect were evaluated: one from the central area of the defect, two from the periphery, and two from the areas between them.

\section{RESULTS}

Microscopic findings bone defec from all the experimental rats exhibited gns bone re air and neither inflammatory infiltr ces no fibr ateration were presented. Histological a lysi onowed osteoblastic activity two weeks

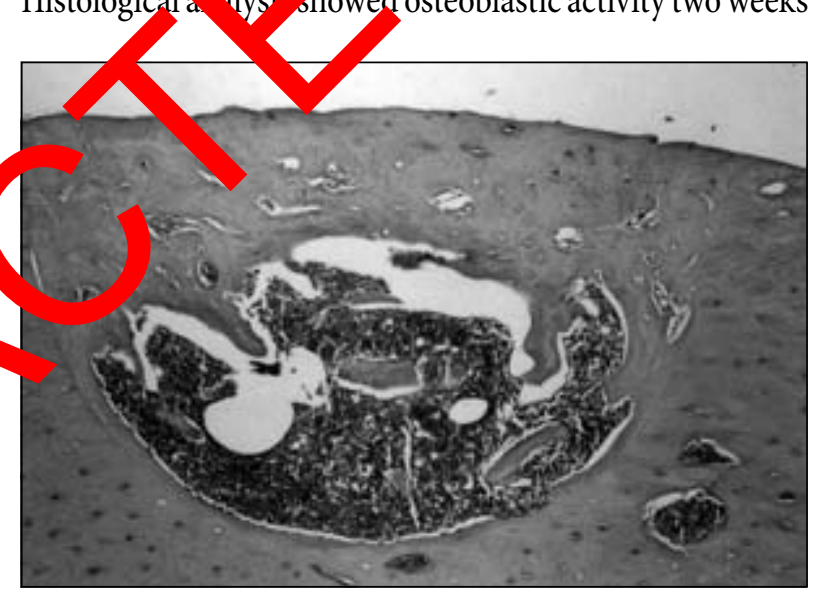

Figure 4. Three weeks after surgery, experimental bone defects completely filled with spongious, lamellar bone with sparse areas of bone marrow (H.E. 20x)

Slika 4. Tri nedelje posle operacije eksperimentalna oštećenja kosti su potpuno ispunjena sunđerastom lamelarnom kosti s retkim oblastima koštane srži (H.E. 20x)

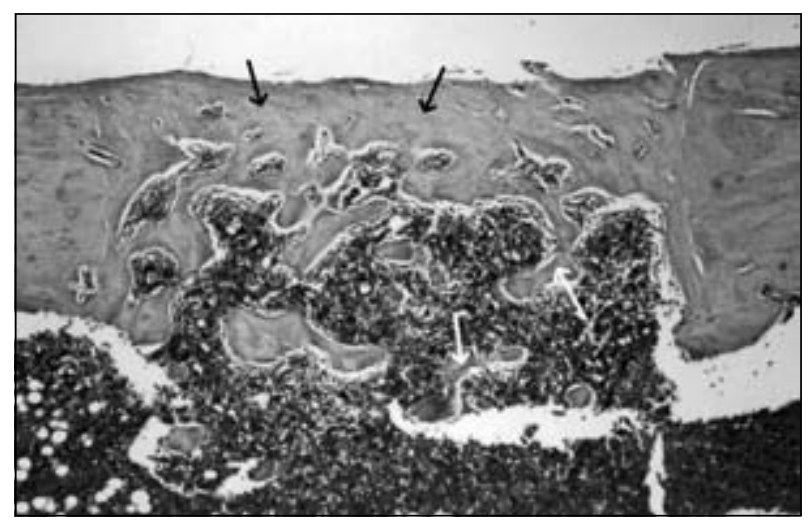

Figure 5. Non-treated bone defects revealed mature lamellar bone at the periphery areas, and immature bone (white arrow) at the central areas after three weeks (H.E. 20x)

Slika 5. Posle tri nedelje nelečena oštećenja kosti sa zrelom lamelarnom kosti u perifernim delovima i nezrelom kosti (bela strelica) u centralnim delovima (H.E. 20x) 
after surgery in all the investigated areas of bone defects of the experimental side. Defects of the femur treated with the low-power laser were filled to a great extent by mature lamellar bone of trabecular nature (Figure 2). Two weeks after surgery, in the defects of the control group, a new bone formation activity was noticed. Newly formed bone sprouts were found at the periphery of bone defects while fibroblastic tissue with no signs of new bone formation was noticed in the central area of the bone defects (Figure 3).

Three weeks after surgery, experimental bone defects were completely filled with cancellous, lamellar bone with sparse areas of bone marrow (Figure 4). Non-treated bone defects revealed mature lamellar bone at the periphery areas and still immature bone, characterized by thin bony trabeculae, at the central areas (Figure 5).

\section{DISCUSSION}

Healing and regeneration of bone defects is still an important phenomenon, of special interest to surgeons. Bone response to trauma generally follows basic wound healing processes. Injury initiates well-defined cascade of tissue reaction in order to produce a new matrix for repairing bone continuity and architecture. The order of these events is bone-specific and depends on the functional differences between various bones [7].

Experimental studies on the effect of a surgical intervention per se have been studied on different experimental models, mainly on long bones. The general impression is that the diameter of the defect greatly in ues es the rate, speed, and quality of healing $[8,91 \mathrm{~m} \mathrm{ani}$,al models, defects greater than $3 \mathrm{~mm}$ in di net ad to heal slower than smaller defects. Hay o that in ind, the defects created in our study con bo onsidere as being relatively large.

After some surgical proce ares which create bone defects in the maxilla or th na able, the coagulum retraction inside the def mig cause appearance of "dead spaces", an' prolit ration connective tissue into the defect. Th an wown formation of new bone tissue and cause a tomic deformity and functional disturbance [10].

The stimulating effect of low power laser on connective-tissue and bone regeneration has been established both clinically $[5,6,11,12]$ and experimentally $[12,13$, 14]. Nagasawa [12] in his study used the low power laser (GaAlAs) for radiation of bone defects on the rat's femur and found active formation of cancellous bone with trabeculae. In the group without laser treatment, he found only a few osteoclasts and some cancellous bone and trabeculae. Jovanović et al [14] studying the effect of the same low power laser on wound healing after tooth extraction in dogs, found a favourable effect of laser irradiation, reflected in quicker epithelium regeneration, creation of granular tissue and fibroplasia. However, there is a strong belief that experimental animal studies do not reflect the human situation [15].

The results of this study on rats showed that the use of a $637 \mathrm{~nm}$ GaAlAs low-power laser with the power output of $50 \mathrm{~mW}$ and $4 \mathrm{~J} / \mathrm{cm}^{2}$ per defect had an obvious influence on the speed of healing of bone defects. The histopathologic investigations carried out in rat femurs pointed out the fact that laser enhances bone regeneration. A positive effect was present especially in early stages of wound healing (2-3 weeks after the creation of bone defects), accelerating the process of bone healing for approximately a week. The strong bio-stimulating effect of low power laser on the process of healing bone defects, noticed earlier has been confirmed also in this experimental model [5]. Additionally, to confirm this laser effect in clinical situations, further investigations are needed.

\section{REFERENCES}

1. Robbins SL. Inflammation and re mo RS, Kumar V, Robbins SL, editors. Robbin's Patho y Basis of sease. PhiladelphiaLondon-Tokyo: WB Saunders 1994. p.5 92.

2. Cawson RA. Essential of dental rgery d pathology. 2nd ed. Edinburgh-Londor New Yo ${ }^{\prime}$ : Chu, Livingstone; 1970. p.147. 3. Revell P. Pathology Bop Berlin: Springer Verlag; 1986.

4. Hammerle Karr 4. Guid bone regeneration at oral implant sites iodontolos, 20 . 1998(17):151-75.

5. Kokino M, Toz R, Alatli My Yemelli Y, Berkman M, Altug T. Effect of laserirradiation tendom healing. Proc. International Congress Laser in Medicine and Surgery, Bologna, 1986. p.405-12.

6. Cokino M, Tzun R, Alatli M, Temelli Y, Berkman M, Altug T. An vestigation $f$ the simulating effect of laser in callus in the treatt of frac res. Proc. International Congress on Laser in Medicine and sury, Bologna, 1986. p.387-93.

mons DJ. Fracture healing perspectives. Clin Orthop. 1985(200):100-13.

Shapiro F. Cortical bone repair. The relationship of the lacunar-canalicular system and intercellular gap junctions to the repair process. J Bone Joint Surg Am. 1988; 70(7):1067-81.

9. Wang J. Spatial orientation of the microscopic elements of cortical repair bone. Clin Orthop. 2000; (374):265-77.

10. Bramley PA. Cysts of the jaws and oral soft tissues. In: Moore JR, editor. Surgery of the Mouth and Jaws. Oxford-London-EdinburghBoston-Palo Alto-Melbourne: Blackwell Scientific Publications; 1985. p.422-4.

11. Kawamura M. Effect of Nd:YAG and diodelaser irradiation on periodontal wound healing. Innov Techn Biol Med. 1990; 11(1):113-8.

12. Nagasawa A. Application of LLLT in dentistry. In: Ohshiro T, editor. Low reactive laser therapy - practical application. Chichester: John Wiley and Sons; 1991. p.76.

13. Eversole LR, Rizoiu I, Kimmel A. Osseous repair subsequent to surgery with an erbium hydrokinetic laser system. International Laser Congress, Athens, 1996. p.213-22.

14. Jovanović G, Minić A, Todorović Lj. Low power laser effects on wound healing after tooth extraction - an experimental study. Serbian Dental Journal. 1998; 45:15-8.

15. Neckel C, Kukiz P. Biostimulation: A comparative study in the postoperative outcome of patients after third molar extraction. J Oral Laser Applications. 2001; 1:215-9.

\author{
Address for correspondence \\ Radojica Dražić \\ Clinic of Oral Surgery \\ School of Dentistry \\ Dr Subotića 4, 11000 Belgrade \\ Serbia \\ Tel.: +381 (0)63288535 \\ Email: raddraz@sbb.rs
}




\title{
Uticaj lasera male snage na zarastanje oštećenja kosti: eksperimentalno istraživanje
}

\author{
Aleksa Marković, Radojica Dražić, Snježana Čolić \\ Klinika za oralnu hirurgiju, Stomatološki fakultet, Univerzitet u Beogradu, Beograd, Srbija
}

\begin{abstract}
KRATAK SADRŽAJ
Uvod Laseri male snage utiču na proces zarastanja rana, koji odlikuju proliferacija fibroblasta, brže stvaranje kolagena i pojačana aktivnost enzima. Cilj ovog rada je bio da se proceni efekat lasera male snage na zarastanje veštački izazvanih oštećenja kosti laboratorijskih pacova.

Materijali i metode rada $U$ istraživanju je korišćeno 10 albino vister pacova. Kod svakog od njih su na obe butne kosti načinjena okrugla oštećenja ( $3 \mathrm{~mm}$ široka i $2 \mathrm{~mm}$ duboka), s tim da je desna bila eksperimentalna strana, a leva kontrolna. Eksperimentalne strane su svakodnevno tretirane galijum-aluminijum-arsenid (GaAlAs) mekim laserom (Medicolaser 637, Technoline, Belgrade, Serbia) s izlaznom snagom od $50 \mathrm{~mW}$, koristeći $4 \mathrm{~J} / \mathrm{cm}^{2}$ po oštećenju tokom sedam dana. Kontr tano zarastu. Efekti ozračenosti laserom su procenjivani dve i tri nedelje posle operacije.

Rezultati Dve nedelje nakon operacije histološkom analizom oštećenja kosti eksperimentå strane uod na je snažna aktivnost osteoblasta. $U$ isto vreme na kontrolnoj strani zapaženi su novoformirani koštani izdar nna pe 'eriji ošt enja kosti, odnosno fibroblastično tkivo bez znakova stvaranja nove kosti u centralnom delu oštećenja. Inedelje na n eracije eksperimentalna oštećenja kosti su potpuno bila ispunjena sunđerastom lamelarnom kosti, dok s etreti ha oštecu ma kosti odlikovale zrela lamelarna kost na perifernim delovima i nezrela kost u centralnim delovima.

Zaključak Dobijeni nalazi pokazuju da korišćenje lasera male snage može z laboratorijskih životinja.

Ključne reči: laser male snage; GaAIAs-laser; oštećenje kosti; zarastanio-kosti; akt, ost osteoblasta

Zarastanje kosti je fiziološki proces koji se sasto ods

Cilj ovog rada je bio da se proceni efekat galijum-aluminijumsenid (GaAlAs) lasera male snage na brzinu zarastanja kosti kod veštački stvorenih oštećenja kosti laboratorijskih pacova.
\end{abstract}

\section{UVOD} za: indukcije akutnog zapaljenja, regeneraci tarenb hskih ca lija, migracije i proliferacije parenhims $\rightarrow \mathrm{i}$ co in ezivnog ekiva, sinteze proteinskog i vanćelijsko a atriksa, $\mathrm{p}$ oblikovanja vezivnog tkiva i parenhimske kor pono e i stvara.ja kolagena [1]. Vađenje zuba i uklanj, fe hronično eriapikalne lezije ponekad dovodi do oštećer viličn kosti. Slicno opštem obrascu, i zarastanje koštane s. lijn akon vađenja zuba se odvija u fazama [2]. Zaras poc e stva njem krvnih ugrušaka (koji ispunjavaju apljin , orga cijom ugruška, epitelizacijom površine râ a z do stvaranja tzv. woven kosti $\mathrm{u}$ vezivnom tkivu, mene nezrele kosti (koju odlikuju šupljine bez paralelnih redo trabekularnom kosti (zreli oblik kosti gde su kolagena vlakana u matriksu organizovana u pločice ili lamele usmerene u istom pravcu) i preoblikovanja šupljine [3].

Glavni preduslov za normalno funkcionisanje kosti je neometano zarastanje njenih oštećenja i ispunjavanje rane koštanim tkivom. Nakon stvaranja oštećenja kosti kod ljudi (posle vađenja zuba ili periapikalne hirurške intervencije) potrebno je oko šest meseci za stvaranje lamelarne kosti, a znatno duži vremenski period da se oštećenje potpuno ispuni zrelim koštanim tkivom.

Danas ne postoji idealna tehnika za stimulaciju zarastanja rana i koja podstiče bržu regeneraciju kosti. Regenerativni postupak nije ubrzan čak ni sa novim materijalima za zamenu kosti [4]. Mnogi podaci iz literature ukazuju, međutim, na stimulišuće dejstvo tzv. mekog lasera (slabe snage) na proces zarastanja rana $[5,6]$. Njegovo dejstvo odlikuju proliferacija fibroblasta, brže stvaranje kolagena i pojačana aktivnost enzima. Nema, međutim, preciznih podataka o uticaju lasera male snage na brzinu i stepen regeneracije kosti.

\section{MATERIJAL I METODE RADA}

Istraživanje je urađeno na 10 albino pacova soja vistar, prosečne težine od $440 \pm 31$ gram. Postupak je izveden pod intraperitoneumskom anestezijom s nembutalom u dozi od $0,1 \mathrm{ml}$ na $100 \mathrm{~g}$ telesne težine. Ispod desne butne kosti, koja je bila eksperimentalna strana, i leve butne kosti, kontrolne strane, obrijana je koža, potom isečena, a butna kost eksponirana tupim ekarterom. Isečen je periost, a zatim su pomoću čeličnog stvrdla (Slika 1) s obe strane napravljena okrugla oštećenja u kosti (3 mm široka i $2 \mathrm{~mm}$ duboka). Pri stvaranju oštećenja vodilo se računa da se ne eksponira prostor koštane srži. Nakon toga su ketgutom (4-0) ušiveni periost, meko tkivo i koža.

Odmah po operaciji oštećenja s eksperimentalne (desne) strane su svakodnevno tretirana mekim $637 \mathrm{~nm}$ GaAlAs laserom (Medicolaser 637, Technoline, Belgrade, Serbia), s izlaznom snagom od $50 \mathrm{~mW}$, koristeći $4 \mathrm{~J} / \mathrm{cm}^{2}$ po oštećenju. Lečenje je trajalo sedam dana, a tretirana oblast je obuhvatala kožu oko oštećenja i samo oštećenje. Oštećenja kosti s kontrolne (leve) strane su ostavljena da spontano zarastu.

Polovina laboratorijskih životinja (pet pacova) je žrtvovana dve nedelje posle operacije, a druga polovina (četiri pacova) posle tri nedelje. Butne kosti su potpuno izvađene i fiksirane $\mathrm{u}$ desetoprocentnom formalinu, a zatim ostavljene $\mathrm{u}$ dvadesetoprocentnoj etilendiamin-tetraosetnoj kiselini (EDTA) tokom dve nedelje. Dekalcifikovani materijal je ukalupljen u parafinske blokove. Uzorci su bojeni hematoksilinom i eozinom 
i analizirani na optičkom mikroskopu. Vršena je evaluacija pet preseka po svakom oštećenju: jedan iz centralnog dela oštećenja, dva s periferije, a dva preseka su uzeta između centralnog i perifernih oštećenja.

\section{REZULTATI}

Mikroskopski nalazi oštećenja kosti svih laboratorijskih pacova su pokazivali znakove reparacije kosti bez izraženih zapaljenjskih infiltrata i fibroznih promena. Na eksperimentalnoj strani histološka analiza dve nedelje nakon operacije je kod svih životinja otkrila aktivnost osteoblasta u svim ispitivanim oblastima oštećenja kosti. Oštećenja lečena laserom male snage su bila popunjena u velikoj meri zrelom lamelarnom kosti trabekularne prirode (Slika 2). Dve nedelje nakon operacije kod na kontrolnoj strani tela pacova takođe je primećeno stvaranje nove kosti. Zapaženi su novoformirani koštani izdanci na periferiji oštećenja, a u centralnom delu je uočeno fibroblastno tkivo bez znakova stvaranja nove kosti (Slika 3).

Tri nedelje posle operacije oštećenja kosti na eksperimentalnoj strani su bila potpuno ispunjena sunđerastom lamelarnom kosti s retkim oblastima koštane srži (Slika 4). Kod nelečenih oštećenja uočene su zrela lamelarna kost na perifernim delovima i nezrela kost sa tankim koštanim trabekulama u centralnim delovima (Slika 5).

\section{DISKUSIJA}

Zarastanje i regeneracija oštećene kosti je i dalje zn cajâ fenomen koji posebno zanima hirurge. Odgovor 1 ti na ${ }^{t}$ aumu je vid procesa obnavljanja tkiva. Kao posl ica ca se javlja dobro definisana kaskada reakcija $y$ avu koje - araju novi matriks, kako bi vratili kontinuitet arhito uru kosti.nok ovih reakcija je specifičan za svaku $\mathrm{k}$, , a zavisi ov 'unkcionalnih razlika kosti [7].

Eksperimentalna istraživanjà tica nirurške intervencije $i$ stvaranja oštećenja kosti n ljno, sštano loči, kao i praćenje procesa zarastanja, , ođen e na rà n eksperimentalnim uzorcima, ali se ugla m $\mathrm{m}$ dugim kostima. Uočeno je da prečnik oštećenja u velikoj meri utiče na stepen i brzinu zarastanja kosti $[8,9]$. Smatra se da na životinjskim uzorcima oštećenja prečnika većeg od $3 \mathrm{~mm}$ zarastaju sporije nego manja. Imajući to na umu, oštećenja koja su načinjeni za potrebe ove studije se mogu smatrati relativno velikim.

U kliničkoj praksi oralne hirurgije vlada značajno interesovanje za ubrzanje procesa zarastanja kosti. Posle hirurških zahvata koji dovode do oštećenja koštanog tkiva u maksili i mandibuli, povlačenje ugruška unutar oštećenja može da izazove pojavu tzv. mrtvih prostora i proliferaciju vezivnog tkiva u oštećenju. Ovo može da uspori stvaranje nove kosti i izazove anatomski deformitet i funkcionalni poremećaj [10].

Stimulišuće dejstvo lasera male snage na vezivno tkivo i regeneraciju kosti je potvrđeno i kliničkim $[5,6,11,12]$ i eksperimentalnim istraživanjima $[12,13,14]$. Nagasava (Nagasawa) [12] je u svom istraživanju koristio laser male snage (GaAlAs) za zračenje oštećenja na butno costi pa va i zapazio aktivno stvaranje sunđeraste kosti sa oštanim tr bekulama. U grupi koja nije bila podvrgnut casers $m$ tretp anu primetio je samo nekoliko osteokl ta i m lo su. aste kosti i trabekule. Jovanović i saradnio 141 , proučavajući dejstvo istoga lasera male snage zarast e ran osle vađenja zuba kod pasa, uočili povo an fekat lasen zračenja koji se ogledao u bržoj regeneraciji ep. la, stvaranju granularnog tkiva i fibroplaziji. M autm, osnovns emali problem je to što se eksperimental a istraživaria na životinjama ne mogu jednostavno preneti i ljudsku si laciju [15].

Ru ltati ašeg istraživanja na pacovima pokazuju da je išćenje $637 \mathrm{~nm}$ GaAlAs lasera male snage, s izlaznom snam ou $50 \mathrm{~mW}$ i $4 \mathrm{~J} / \mathrm{cm}^{2}$ po oštećenju, imalo pozitivan uticaj na brzinu izlečenja oštećene kosti. Histopatološka ispitianja obavljan na butnim kostima pacova ukazala su i na činjenicu da je regeneracija kosti bila brža pod uticajem lasera. Pozitivan efekat zračenja bio je značajan naročito u ranim fazama zarastanja rane (dve-tri nedelje od stvaranja oštećenja kosti) i značajno je ubrzao proces zarastanja kosti za oko jednu nedelju. Snažni biostumulišući efekat lasera male snage na proces zarastanja kosti koji je ranije primećen potvrđen je i u ovom eksperimentalnom modelu [5]. Ali da bi se ovaj efekat potvrdio i u kliničkim uslovima, neophodna su dodatna klinička istraživanja. 